\title{
PERUBAHAN TARI GANDAI PADA MASYARAKAT MUKOMUKO PROVINSI BENGKULU
}

\author{
Marfinetri Elyadi $^{1^{*}}$, Lora Gustia Ningsih ${ }^{2 *}$ \\ Minat Studi Pengkajian Seni Tari Program Pascasarjana \\ Institut Seni Indonesia Padangpanjang \\ Jl. Bahder Johan, Guguak Malintang, Padangpanjang, Kota Padangpanjang, 27126. \\ Sumatera Barat. Indonesia \\ Email: marfinetrielyadi@yahoo.com
}

\begin{abstract}
Abstrak
Tari gandai merupakan sebuah tari tradisi yang ada di Mukomuko provinsi Bengkulu. Tari ini berasal dari cerita rakyat Malin Deman dan Puti Bungsu, Malin Deman merupakan manusia bumi dan Puti Bungsu merupakan manusia langit. Tari ini awalnya ditarian untuk menghibur Puti Bungsu yang berpisah dengan Malin Deman. Tari ini di tarian oleh beberapa penari perempuan secara berpasangpasangan. Gerakan tari Gandai di ambil dari gerakan satwa yang mengambarkan kekecewaan malin deman yang ditinggal oleh Puti Bungsu. Pada saat ini tarian ini sudah berubah menjadi tari untuk hiburan dalam acara-acara perkawinan ataupun acara pesta rakyat di Kabupaten Mukomuko. Tari ini memiliki Sembilan gerak sesuai dengan lobang pada serunai gandai. Serunai gandai merupakan alat musik pengiring dalam tarian gandai. pada saat ini tari gandai sudah mengalami perubahan, baik dari segi bentuk tari maupun dari segi fungsi. Tujuan penelitian ini adalah untuk mengungkap bagaimana perubahan tari Gandai pada masyarakat Mukomuko Provinsi Bengkulu metode yang digunakan adalah metode kualitatif, pengumpulan data dilakukan melalui observasi dan mengamati tari Gandai tradisi dan kreasi.
\end{abstract}

Kata Kunci: tari gandai, perubahan, Mukomuko.

\begin{abstract}
Gandai dance is a traditional dance in mukomuko, Bengkulu province. This dance comes from the folklore Malin Deman and Puti Bungsu, Malin Deman is an earth man and the youngest Puti Bungsu is a celestial man. This dance was originaly danced to entertain Puti Bungsu who parted ways with Malin Deman. This dance is danced by several female dancers in pairs. The Gandai dance movement was taken from the animal movement which depicted the disappointment of Malin Deman who was left by the youngest Puti. At this time the dance has turned into a dance for entertainment in weddings or folk parties in Mukomuko District. This dance has nine movements inaccordance with the hole in yhe smart alley. The clever grun is a musical instrument accompaniment in smart dance. At this time the smart dance has undergone changes, both in terms of dance form and in terms of dance form and in terms of function. The purpose of this study was to reveal how the change of smart dance in the Bengkulu Province Mukomuko community method used was a qualitative method, data collection was carried out through observation and observing the traditional dance of tradition and creation.
\end{abstract}

Keywords: gandai's dance, change, Mukomuko.

\section{PENDAHULUAN}

Tari gandai ini dipercaya berasal dari kisah atau mitos Malin Deman dan Puti Bungsu. Cerita tentang Malin Deman tersebut, mengisahkan tentang riwayat pernikahan Malin Deman dengan Puti Bungsu. Malin Deman adalah manusia bumi, sedangkan Puti Bungsu merupakan manusia langit, anak bungsu dari 7 bidadari langit bersaudara.

Tari gandai pada awalnya bertujuan untuk menghibur Puti Bungsu yang telah dikecewakan oleh Malin Deman. Bahkan gerakan-gerakan yang terdapat di tari gandai sesungguhnya merupakan gambaran kekecewaan Puti Bungsu, dan penyesalan Malin Deman atas kekeliruannya. Gerakan-gerakan tari gandai yang banyak memunculkan gerakan satwa, merupakan refleksi dari masa pencarian Puti Bungsi oleh Malin Deman dan mengamati gerakan satwa yang ditemuinya dalam pencarian itu(Marlis Caniago, 2018). Dalam perkembangannya pelaksanakan atau pertunjukan tari gandai oleh masyarakat Mukomuko berubah menjadi tari untuk menghibur atau memberi semangat masyarakat yang sedang bekerja mempersiapkan segala sesuatu dalam pelaksanaan 
bimbang, memulai pekerjaan ke sawah (bertani) serta ketika padi sudah panen.

Tari gandai tidak hanya berkembang dari segi tujuan pertunjukan tetapi juga dalam segi bentuk, dimana tari gandai tradisi memiliki 9 (Sembilan) gerak, dengan alat musik yang terdiri dari 3 (tiga) instrument. Setelah adanya perkembangan, tari gandai dikembangkan menjadi tari kreasi yang memiliki berbagai macam gerak dan juga tambahan dalam segi instrument musik. Tari gandai tradsi dan kreasi ini tetap berjalan seiring dimana tidak ada salah satu dari mereka yang terlupakan, sehingga tari gandai ini masih lestari dan hidup sampai saat ini yang kreasi maupun yang tradisi. Hal ini lah yang membuat peneliti tertarik untuk meneliti tari gandai dalam perspektif tranformasi atau perubahan tari gandai. Berdasarkan penjelasan di atas, dapat disimpulkan, ada beberapa rumusan masalah untuk mengungkap perubahan tari Gandai yang terdapat di kabupaten Mukomuko Provinsi Bengkulu, Rumusan masalah dari penelitian ini yaitu: Bagaimana bentuk tari Gandai di Kabupaten Mukomuko

Tujuan dari penelitian ini adalah untuk mengetahui bentuk dari tari Gandai yang terdapat di Kabupaten Mukomuko.

\section{KAJIAN TEORI}

Membicarakan perubahan tentu tidak terlepas dari perbedaan keadaan yang diamati antara sebeum dan sesudahnya dalam waktu tertentu. Untuk menyatakan perbedaannya, piotr sztompka menyatakan dasar perubahan sosial mencakup tiga gagasan yakni: (1) perbedaan; (2)pada waktu berbeda; dan (3) diantara keadaan sistim sosial yang sama Untuk memahami perbedaan yang terdapat pada tari gandai dapat dilihat berdasarkan konteks dahulu dan kini.Sejalan rentang waktu, budaya pun berubah mengikuti zamanya. Ketika terjadi proses pembudayaan melalui sistim pewarisan maka muncul bentuk baru dari kebudayaan sekelompok individu.

\section{METODE PENELITIAN}

Penelitian ini berupa penelitian kualitatif adalah metode penelitian yang dilakukan untuk meneliti pada kondisi obyek yang alamiah, (sebagai lawanya adalah eksperimen) dimana penelitian ini sebagai instrumen kunci, teknik pengumpulan data dilakukan secara gabungan (Sugyiono, 2015: 247). Penelitian kualitatif adalah penelitian yang objeknya alamiah. Objek yang alamamiah adalah objek yang berkembang apa adanya, tidak dimanipulasi oleh peneliti dan kehadiran peneliti tidak mempengaruhi dinamika pada objek tersebut. Penelitian ini menggunakan kualitatif yang bersifat deskriptif, sehingga data yang dikumpulkan berbentuk kata-kata atau gambar. Peneliti mengunakan jenis penelitin kualitatif dikarenakan metode ini membantu untuk menggumpulkan data yang benar- benar nyata saat dilapangan dan membantu menemukan masalah dalam penelitian, metode kualitatif dapat menghasilkan informasi yang akurat, dalam penelelitian ini peneliti ingin mendiskripsikan tentang permasalahan yang ada dilapangan. Meneliti bagaimana perubahan dari Tari Gandai pada masyarakat Mukomuko Provinsi Bengkulu, Metode ini juga dapat mengumpulkan data dari beberapa yaitu hasil wawancara dan observasi.

\section{HASIL DAN PEMBAHASAN \\ 1.Hasil}

Sebuah kesenian tradisional (seni tradisi), pada dasarnya bertujuan untuk menghibur audience atau penontonnya, dan menjadi sesungguhnya personifikasi kehidupan sosial budaya masyarakat pengembannya. Demikian pula dengan kesenian gandai pada masyarakat Mukomuko di Provinsi Bengkulu, yang ditampilkan pada pelaksanaan bimbang (pesta perkawinan), penyambutan tamu, dan lainnyapada hakikatnya untuk menghibur yang menontonnya. Penampilan atau pertunjukan tari gandai pada acara-acara tersebut, dimaksudkan untuk menghibur penonton yang hadir, seperti pada acara bimbang adalah orang-orang yang sedang bekerja mempersiapkan segala sesuatu tentang pesta perkawinan (bimbang adat), sedangkan pada waktu penyambutan tamu dan lainnya adalah para tamu yang hadir pada acara tersebut.

Konon, pada awalnya dahulu penampilan kesenian (tari) gandai adalah dalam rangka menghibur Puti Bungsu yang telah dikecewakan oleh Malin Deman. Bahkan gerakan-gerakan yang terdapat tari gandai sesungguhnya merupakan personifikasi kekecewaan Puti Bungsu, dan penyesalan Malin Deman atas kekeliruannya. Gerakan-gerakan tari gandai yang banyak memunculkan gerakan satwa, merupakan refleksi dari masa pencarian Puti Bungsi oleh Malin Deman dan mengamati gerakan satwa yang ditemuinya dalam pencarian itu. Dalam perkembangannya hal itu menjadi tari yang dilaksanakan oleh masyarakat setempat sebagai tari gandai yang dikenal sekarang ini.

\section{Pembahasan}

Asal usul keberadaan gandai pada masyarakat Mukomuko , sama-sama dipercaya berasal dari kisah atau mitos Malin Deman dan Puti Bungsu. Cerita tentang Malin Deman tersebut, mengisahkan tentang 
riwayat pernikahan Malin Deman dengan Putri Muhammad Duyah (Garan nan si Bungsu), Malin Deman adalah manusia bumi, sedangkan Putri Muhammad Duyah (Puti Bungsu) merupakan manusia langit, anak bungsu dari 7 bidadari langit bersaudara. Pernikahan Malin Deman dengan Puti Bungsu terjadi karena Malin Deman mencuri atau menyembunyikan selendang Puti Bungsu yang sedang mandi, sehingga ia tidak dapat kembali bersama keenam saudaranya ke daerah asalnya. Perkawinan Malin Deman dan Puti Bungsu berakhir dengan perpisahan karena Malin Deman tidak dapat meninggalkan kebiasaannya menyabung ayam, dan setelah Puti Bungsu menemukan kembali bajunya sehingga bisa terbang dan kembali ke langit.

Penamaan gandai ,tari gandai berasal dari kata gando (ganda). Oleh karena masyarakat Mukomuko biasanya mengucapkan kata ganda yang berarti dua atau berpasangan dengan sebutan "gando", kemudian secara perlahan disebut dan dikenal oleh masyarakat Mukumuko dengan kata "gandai".

Sebuah kesenian tradisional (seni tradisi), pada dasarnya bertujuan untuk

menghibur audience atau penontonnya, demikian pula dengan kesenian gandai pada masyarakat Mukomuko di Provinsi Bengkulu, yang ditampilkan pada pelaksanaan bimbang (pesta perkawinan), penyambutan tamu, dan lainnya pada hakikatnya untuk menghibur yang menontonnya. Penampilan atau pertunjukan tari gandai pada acara-acara tersebut, dimaksudkan untuk menghibur penonton yang hadir, seperti pada acara bimbang adalah orangorang yang sedang bekerja mempersiapkan segala sesuatu tentang pesta perkawinan (bimbang adat), sedangkan pada waktu penyambutan tamu dan lainnya adalah para tamu yang hadir pada acara tersebut. pada awalnya dahulu penampilan kesenian (tari) gandai adalah dalam rangka menghibur Puti Bungsu yang telah dikecewakan oleh Malin Deman.

Pada waktu penyambutan tamu dan lainnya itu, biasanya tari gandai ditampilkan di acara pembukaan sebagai hiburan bagi tamu-tamu yang menjadi sajian estetis. Tari gandai yang disajikan pun berbeda dengan pertunjukan tari gandai dalam acara pesta perkawinan. Pada acara kenegaraan tari gandai ditampilkan dengan durasi waktu lebih kurang 10 menit pada malam hari, sedangkan pada acara pesta perkawinan tari gandai ditampilkan dengan durasi waktu lebih kurang 7 jam (Roza, 2011; 67).
Gorga Jurnal Seni Rupa

Volume 08 Nomor 02 Juli-Desember 2019 p-ISSN: 2301-5942 | e-ISSN: 2580-2380

Tari gandai tersusun dari rangkaian beberapa pola bentuk kesatuan (ragam) gerak. Gerakan-gerakan dalam tari gandai yang menonjol adalah gerakan yang menggunakan kaki dan tangan, yang sudah terbentuk telah terbentuk sejak dahulu (turun temurun) dan mengandung makna masing-masingya. Disamping itu, gerakan tari gandai cenderung menggunakan formasi lingkaran dalam setiap tarinya. Kekhasan gerak dari tari gandai adalah dalam sajiannya banyak menggunakan gerakan kaki dan tangan yang mereka lakukan dengan semangat. Menurut Pakpahan (2014;70), gerakan-gerakan yang terbentuk dalam gandai telah terstuktur ataupun terpola dalam aturanaturan adat dan nilai keindahan setempat secara simbolis serta memiliki makna-makna tersendiri.

Pada dasarnya gerakan dalam tari gandai pada dasarnya meniru gerakan-gerakan binatang seperti;

1). Alang manari (lori), meniru gerakan burung elang yang sedang menari di udara, 2). Rantak kudo, meniru rentak atau jalan kuda, 3). Siamang bajapai, meniru siamang yang sedang bergayutan (bergantung pada dahan kayu, 4). Gajah mendorong, meniru gajah sedang mendorong, 5). Menjong bebek, meniru gerakan menjong bebek, 6). Kuou lentok (burung kuok litak), menirukan burung kuau sedang kelaparan (letok/litak), 7). Menjong kecik, meniru gerakan menjong kecil, 8). Menjong gedang, meniru gerakan menjong besar, dan 9). Puyuh belago, meniru gerakan burung puyuh sedang berkelahi.

Alat musik pengiring. Musik menjadi unsur penting dan tidak bisa diabaikan karena keberadaan alat musik membuat tari gandai lebih enak untuk dilihat dan bermakna. Adapu alat music pengiring tari Gandai yaitu Sereunai, Redap dan pantun.

\section{KESIMPULA DAN SARAN}

\section{Kesimpulan}

Kesenian gandai merupakan seni tradisi berbentuk tari yang terdapat dalam kehidupan masyarakat Mukomuko di Provinsi Bengkulu, yang telah dikenal sebagai kekayaan budaya/seni masyarakat setempat sejak dahulu hingga sekarang. Tari gandai memiliki 9 gerakan yang di mulai dari gerak lory sebagai gerak inti dari tari gandai , tanpa gerak lory tarian tersebut tidak biasa disebut tari gandai.

Tari gandai merupakan tarian yang bersifat tradisi dan bertujuan untuk menghibur masyarakat dimalam sebelum hari pesta pernikahan di muko-muko, dapat dilihat pada geraknya yang licah dan alunan musinya. Tarian ini ditarikan oleh penari yang dimasuki arwah dari roh dewa-dewaan yang dipanggila pada gerak tak suah 
Musik yang mengiringi tari gandai yaitu dengan instrumen musik, musik dan tari merupakan bagian terikat yang saling mendukung untuk pertunjukan kesenian. Adapun alat musik yang digunakan untuk mengiringi pertunjukan tari gandai tersebut sudah dijelaskan sebelumnya yaitu serunai gandai atau sonai, rebana atau odap, dan Bagi masyarakat Mukomuko, fungsi kesenian gandai pada awalnya dimaksudkan untuk menjadi penyemangat atau menghibur orang-orang yang sedang bekerja, kemudian berkembang menjadi media pembelajaran dan memperkuat solidaritas sosial (pemersatu) di tengah masyarakat. Melalui pantun gandai, bisa disampaikan nila-nilai budaya atau norma sosial kepada penontonnya, terutama generasi muda. Tari gandai sebagai khasanah budaya masyarakat Mukomuko telah menjadi salah sati identitas budaya masyarakat setempat yang tetap bertahann walaupun dewasa ini pengaruh arus globalisasi informasi dan komunikasi tidak terhindarkan, juga menyentuh kesenian gandai. Perubahan-perubahan pada dasarnya merupakan penyesuaian atau adaptasi pelaksanaan kesenian gandai dalam menyikapi perkembangan zaman yang sesungguhnya tidak menghilang substansi tari gandai sebagai kesenian tradisional.

\section{Saran}

Berkaitan dengan penelitian mengenai tari Gandai yang terdapat di Kabupaten Mukomuko, harus tetap melestarikan dan memerhatikan keberlanjutan kebudayaan maupun kesenian tradisional yang terdapat di daerah kita. Sangatlah penting untuk tetap melestarikannya supaya tidak tergerus oleh zaman. Penulis berharap pemerintah berperan terhadap kesenian tradisi yang ada di daerah-daerah terutama tari Gandai yang ada di Kabupaten Mukomuko Provinsi Bengkulu.

\section{DAFTAR RUJUKAN}

Pakpahan, Frita Anjelina. (2014) Tradisi Gandai dalam Konteks Upacara perkawinan pada Masyarakat Pekal di Kecamatan Ketahun Kabupaten Bengkulu Utara: Deskripsi Pertunjukan, dan Fungsinya (Skripsi). Medan: FIB USU.

Roza, Zasmili Inda. (2011) Fungsi Tari Gandai dalam Kehidupan Masyarakat Mukomuko Kabupaten Mukomuko Provinsi Bangkulu (Tesis). Padang Panjang: Program Pasca Sarjana Institut Seni Indonesia.

Sztompka, Piotr, Pitrim Sorokin, (2008). Sosiologi Perubahan Sosial. Jakarta: Prenada.

Sugyiono. (2015). Penelitian Kulitiatif. Bandung: Alfabeta.

Wawancara: Marlis Chaniago. 17 Januari 2018. Seniman Mukomuko. Mukomuko. 